\title{
Effects of climate and forest age on the ecosystem carbon exchange of afforestation
}

\author{
Zhi Chen ${ }^{1,2} \cdot$ Guirui Yu ${ }^{1,2} \cdot$ Qiufeng Wang ${ }^{1,2}$
}

Received: 25 October 2018/Accepted: 12 March 2019/Published online: 22 April 2019

(C) The Author(s) 2019

\begin{abstract}
Afforestation is believed to be an effective practice to reduce global warming by sequestering large amounts of carbon in plant biomass and soil. However, the factors that determine the rate of carbon sequestration with afforestation are still poorly understood. We analyzed ecosystem carbon exchange after afforestation based on eddy covariance measurements with the aim to identify factors responsible for the rate of carbon exchange following afforestation. The results indicated that afforestation in the tropical/subtropical and temperate climate zones had greater capacities for carbon sequestration than those in boreal zones. Net ecosystem production (NEP), gross primary production (GPP) and ecosystem respiration (RE) varied greatly with age groups over time. Specifically, NEP
\end{abstract}

Project funding: The work was supported by the National Natural Science Foundation of China (Nos. 31600347 and 41501381), National Key Research and Development Program of China (No. 2016YFA0600103), and International Partnership Program of Chinese Academy of Sciences (No. 121311KYSB20170004).

The online version is available at http://www.springerlink.com

Corresponding editor: Tao $\mathrm{Xu}$.

Zhi Chen

chenz@igsnrr.ac.cn

$\triangle$ Guirui Yu

yugr@igsnrr.ac.cn

1 Synthesis Research Center of Chinese Ecosystem Research Network, and Key Laboratory of Ecosystem Network Observation and Modeling, Institute of Geographic Sciences and Natural Resources Research, Chinese Academy of Sciences, Beijing 100101, People's Republic of China

2 College of Resources and Environment, University of Chinese Academy of Sciences, Beijing 100049, People's Republic of China was initially less than zero in the $<10$ year group and then increased to its peak in the 10-20 year group. Afforestation of varied previous land use types and planting of diverse tree species did not result in different carbon fluxes. The general linear model showed that climate zone and age of afforestation were the dominant factors influencing carbon sequestration. These factors jointly controlled $51 \%, 61 \%$ and $63 \%$ of the variation in NEP, GPP and RE, respectively. Compared to the strong regulation of climate on GPP and RE, NEP showed greater sensitivity to the age of afforestation. These results increase our understanding of the variation in ecosystem carbon exchange of afforestation and suggest that afforestation in subtropical and temperate areas after 20 years would yield greater carbon sink benefits than would afforestation of boreal regions.

Keywords Afforestation - Carbon sequestration - Eddy covariance $\cdot$ Climate $\cdot$ Age

\section{Introduction}

Afforestation is defined as planting trees on land that was previously treeless for at least 50 years (Berthrong et al. 2009) and has been posited as an effective approach to sequester carbon (C) and mitigate global warming (Wright et al. 2000; Metz et al. 2007; Lal 2008). Globally, the area of afforestation has increased rapidly at a rate of 4 million hectares per year during recent decades (FAO 2017). By 2015, the global afforestation area reached 293 million hectares (FAO 2017). Understanding the magnitude of carbon sequestration and the related controlling factors of such extensive afforestation is of great importance for policy making in relation to global climate mitigation. 
Afforestation greatly affects ecosystem $\mathrm{C}$ dynamics by altering land cover, $\mathrm{C}$ input and turnover, and thus impacts $\mathrm{C}$ sequestration and loss (Guo and Gifford 2002; Laganière et al. 2010; Li et al. 2012). It is believed that afforestation has a great potential to store $\mathrm{C}$ through plant biomass and soil C accumulation (Jandl et al. 2007). Plantations with perennial vegetations usually result in higher plant biomass and longer rotations. On the other hand, the presence of vegetations can ameliorate adverse microclimatic conditions and enhance physical structure of habitats, reduce erosion and nutrient leaching, and thus enhance $\mathrm{C}$ storage (Six et al. 2000). Changes in C storage are directly regulated by the balance of $\mathrm{C}$ input and output fluxes (Laganière et al. 2010). To maximize the $C$ sink capacity of afforested areas, it is imperative to understand the mechanisms involved in controlling carbon fluxes after afforestation.

However, the effects of afforestation on $\mathrm{C}$ exchange and the related influencing factors remain unclear. Contrasting reports have suggested that afforestation produces a strong carbon sink (Wolf et al. 2011; Tong et al. 2012), is carbon neutral (Lohila et al. 2007; Don et al. 2009), or produces a strong carbon source (Cai et al. 2011). Wolf et al. (2011) reported that substantial amounts of $\mathrm{C}$ were sequestered by areas that underwent afforestation compared to adjacent pastures. In contrast, Cai et al. (2011) reported net release of $630 \mathrm{~g} \mathrm{C} \mathrm{m}^{-2}$ over 5 years from afforestation with hybrid poplar. These inconsistent results possibly result from the fact that the magnitude and direction of $\mathrm{C}$ exchange are affected by multiple factors, including climate, past land use type, tree species planted, and age of afforestation (Paul et al. 2002; Laganière et al. 2010). However, how these factors affect $\mathrm{C}$ exchange of afforestation are not well understood.

In the present study, we compiled a database of ecosystem $\mathrm{C}$ exchange based on the eddy covariance technique to address the questions of how fast $\mathrm{C}$ can be sequestered in afforested ecosystems and what factors affect this rate. A series of potential controlling factors that influence carbon exchange following afforestation were selected and analyzed, including climate zones, past land use types, tree species planted and age of afforestation. We hypothesized that carbon exchange would be affected by climate and age of afforestation.

\section{Materials and methods}

\section{Data collection}

We compiled data relevant to ecosystem carbon exchange after afforestation from articles that were published before 2019. We performed the literature searches in the ISI Web of Science and China National Knowledge Infrastructure (CNKI) based on the keywords 'afforestation', 'afforest', 'carbon flux', 'carbon sequestration', and 'carbon exchange'. To increase the comparability of data, the following criteria were used to select publications: the carbon flux data should be uniformly measured by eddy covariance techniques (e.g., LI-7200, LI-7500); the ecosystem carbon fluxes following afforestation should be continuously observed for at least one full year. In addition, only sites with specified afforestation practices and clear afforestation time schedules were considered. The studies with ambiguous previous land uses or reforestation programs were excluded from this study. In total, 20 independent flux sites of afforestation were finally selected for our analysis (Table 1).

For each paper, the carbon exchange between ecosystems and the atmosphere, including gross primary production (GPP), ecosystem respiration (RE), and net ecosystem production (NEP) were compiled. In addition, we compiled detailed site information, including data source, site location, latitude, longitude, elevation, soil type, climate zone, mean annual temperature, mean annual precipitation, tree species, previous land use type, and year of afforestation. The dataset contained studies of afforestation ranging from tropical/subtropical and temperate to boreal zones. The planted tree species of afforestation were grouped into broadleaf, pine and spruce. Land use types prior to afforestation were farmland, pasture, and grassland. The years since afforestation were divided into four groups, viz. $<10,10-20,20-40$, and $>$ 40 years. Detailed information for each study site is listed in Table 1.

\section{Data analysis}

The afforestation dataset was classified into different categories in terms of climate zone, age of afforestation, previous land use type and tree species planted. For each category, the mean and standard errors were calculated. One-way analysis of variance (ANOVA) was first used to compare mean carbon fluxes for each category (uncorrected effect). To account for confounding interactive influences among categories, we used analysis of covariance (ANCOVA) to investigate the net effect of one variable by excluding the variation of other variables (corrected effect). Specifically, to test the effect of climate zone (three levels) on carbon fluxes, climate zone was included as the fixed factor with age of afforestation, previous land use type (three levels) and tree species planted (three levels) as covariates. The similar method was followed to test the effects of age of afforestation, previous land use type and tree species planted, respectively. The effects of climate factors (mean annual temperature and 
Table 1 Study site descriptions

\begin{tabular}{|c|c|c|c|c|c|c|c|c|c|c|}
\hline Site name & $\begin{array}{l}\text { Latitude } \\
\left({ }^{\circ} \mathrm{N}\right)\end{array}$ & $\begin{array}{l}\text { Longitude } \\
\left({ }^{\circ} \mathrm{E}\right)\end{array}$ & $\begin{array}{l}\text { Climate } \\
\text { zones }\end{array}$ & $\begin{array}{l}\text { Afforest } \\
\text { time }\end{array}$ & $\begin{array}{l}\text { Previous } \\
\text { land use } \\
\text { type }\end{array}$ & Tree species & $\begin{array}{l}\text { Year of } \\
\text { measurement }\end{array}$ & $\begin{array}{l}\text { MAT } \\
\left({ }^{\circ} \mathrm{C}\right)\end{array}$ & $\begin{array}{l}\text { MAP } \\
(\mathrm{mm})\end{array}$ & References \\
\hline Sardinilla & 9.32 & -79.63 & Tropical & 2001 & Pasture & $\begin{array}{l}\text { Luehea } \\
\text { seemanii, } \\
\text { Cordia } \\
\text { alliodora }\end{array}$ & 2008 & 25 & 2071 & $\begin{array}{l}\text { Wolf et al. } \\
\text { (2011) }\end{array}$ \\
\hline Qianyanzhou & 26.73 & 115.01 & Subtropical & 1985 & Grassland & Masson pine & 2003-2012 & 18.4 & 1488 & $\begin{array}{l}\text { Huang et al. } \\
\text { (2007), Tang } \\
\text { et al. (2016) }\end{array}$ \\
\hline Yueyang & 26.73 & 115.01 & Subtropical & 2000 & Grassland & $\begin{array}{l}\text { Populus } \\
\text { deltoides }\end{array}$ & 2005-2007 & 17.85 & 1954 & Han (2008) \\
\hline Anqing & 29.53 & 112.86 & Subtropical & 1989 & Grassland & $\begin{array}{l}\text { Populus } \\
\text { deltoides }\end{array}$ & 2005-2007 & 17.41 & 1671 & Han (2008) \\
\hline Xiaolangdi & 35.02 & 112.63 & Temperate & 1976 & Grassland & $\begin{array}{l}\text { Cork oak, } \\
\text { black locust }\end{array}$ & 2006-2010 & 15 & 524 & $\begin{array}{l}\text { Tong et al. } \\
\text { (2012) }\end{array}$ \\
\hline WP39-ON & 42.70 & -80.40 & Temperate & 1939 & Grassland & White pine & 2005-2008 & 8.8 & 944 & $\begin{array}{l}\text { Peichl et al. } \\
\quad(2010,2014)\end{array}$ \\
\hline WP74-ON & 42.70 & -80.40 & Temperate & 1974 & Grassland & White pine & 2005-2008 & 8.8 & 944 & $\begin{array}{l}\text { Peichl et al. } \\
\quad(2010,2014)\end{array}$ \\
\hline WP89-ON & 42.70 & -80.40 & Temperate & 1989 & Farmland & White pine & 2005-2007 & 9.1 & 918 & $\begin{array}{l}\text { Peichl et al. } \\
\quad(2010,2014)\end{array}$ \\
\hline WP02-ON & 42.70 & -80.40 & Temperate & 2002 & Farmland & White pine & 2005-2008 & 8.8 & 944 & $\begin{array}{l}\text { Peichl et al. } \\
\quad(2010,2014)\end{array}$ \\
\hline Ontario & 42.71 & -80.37 & Temperate & 1940 & Farmland & White pine & 2003 & 7.8 & 710 & $\begin{array}{l}\text { Arain and } \\
\text { Coupe (2005) }\end{array}$ \\
\hline Mehrstedt & 51.28 & 10.66 & Temperate & 2003 & Pasture & $\begin{array}{l}\text { Broadleaf, } \\
\text { conifer }\end{array}$ & 2004-2006 & 8.5 & 522 & $\begin{array}{l}\text { Don et al. } \\
\text { (2009) }\end{array}$ \\
\hline Dooary-D9 & 52.95 & -7.25 & Temperate & 1993 & Pasture & Sitka spruce & 2002 & 9.95 & 899 & $\begin{array}{l}\text { Black et al. } \\
\text { (2009) }\end{array}$ \\
\hline Dooary-D14 & 52.95 & -7.25 & Temperate & 1988 & Pasture & Sitka spruce & 2002 & 9.95 & 899 & $\begin{array}{l}\text { Black et al. } \\
\text { (2009) }\end{array}$ \\
\hline Dooary-D30 & 52.95 & -7.27 & Temperate & 1972 & Pasture & Sitka spruce & 2002 & 9.95 & 899 & $\begin{array}{l}\text { Black et al. } \\
\text { (2009) }\end{array}$ \\
\hline $\begin{array}{l}\text { Cullenagh- } \\
\text { C45 }\end{array}$ & 52.95 & -7.27 & Temperate & 1957 & Pasture & Sitka spruce & 2002 & 9.95 & 899 & $\begin{array}{l}\text { Black et al. } \\
\text { (2009) }\end{array}$ \\
\hline Alberta & 53.71 & -113.63 & Boreal & 2009 & Farmland & $\begin{array}{l}\text { Hybrid } \\
\text { Poplar }\end{array}$ & 2010-2011 & 3.38 & 405 & $\begin{array}{l}\text { Jassal et al. } \\
\text { (2013) }\end{array}$ \\
\hline Ashmont & 54.35 & -111.52 & Boreal & 1973 & Farmland & $\begin{array}{l}\text { Hybrid } \\
\text { Poplar }\end{array}$ & 2005-2009 & 2 & 349 & $\begin{array}{l}\text { Cai et al. } \\
\text { (2011) }\end{array}$ \\
\hline Skogaryd & 58.38 & 12.15 & Boreal & 1951 & Farmland & $\begin{array}{l}\text { Norway } \\
\text { spruce }\end{array}$ & 2008 & 8.7 & 1006 & $\begin{array}{l}\text { Meyer et al. } \\
\text { (2013) }\end{array}$ \\
\hline Alkkia & 62.18 & 22.78 & Boreal & 2005 & Farmland & Scots pine & 2003 & 2.2 & 330 & $\begin{array}{l}\text { Lohila et al. } \\
\text { (2007) }\end{array}$ \\
\hline Vallanes & 65.19 & -14.56 & Boreal & 1992 & Pasture & $\begin{array}{l}\text { Siberian } \\
\text { larch }\end{array}$ & 2004-2006 & 6.4 & 502 & $\begin{array}{l}\text { Bjarnadottir } \\
\text { et al. (2009) }\end{array}$ \\
\hline
\end{tabular}

MAT mean annual temperature, MAP mean annual precipitation

precipitation) on carbon sequestration of afforestation were analyzed by regression analysis with the residual regressed on age of afforestation. A general linear model (GLM) was built to further identify the individual and interactive effects of temperature, precipitation and age of afforestation. All statistical analyses were performed using SPSS 16.0 software (SPSS Inc., USA). 


\section{Results}

\section{Carbon exchange variation of afforestation by climate zone}

After afforestation, ecosystems acted as carbon sinks in different climate zones (Fig. 1). However, the rate of carbon sequestration varied by climate zone. In boreal zones, afforestation resulted in near-zero NEP $\left(34 \pm 119 \mathrm{~g} \mathrm{C} \mathrm{m}^{-2} \mathrm{a}^{-1}\right)$. Afforestation in tropical/subtropical zones exhibited strong carbon uptake with average NEP of over $400 \mathrm{~g} \mathrm{C} \mathrm{m}^{-2} \mathrm{a}^{-1}$. This was followed by temperate zones, where mean NEP was $314 \pm 78 \mathrm{~g} \mathrm{C} \mathrm{m}^{-2} \mathrm{a}^{-1}$ (Fig. 1a). After eliminating the effects of tree species, land use type, and age, NEP, GPP and RE still differed significantly by climate zone $(p=0.07,0.005,0.002$ for NEP, GPP and RE

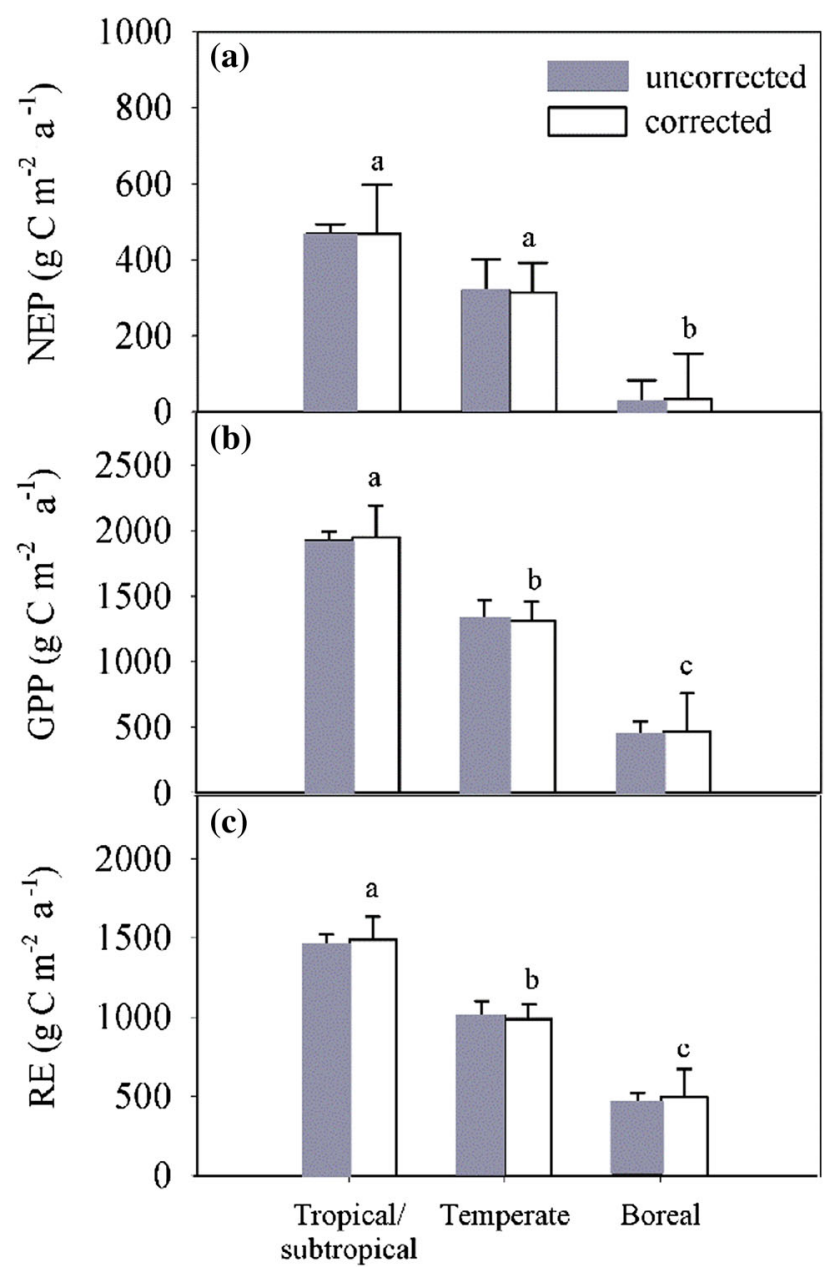

Fig. 1 Carbon exchange of afforestation in different climate zones. a NEP, net ecosystem production; b GPP, gross primary production; c RE, ecosystem respiration. The error bars represent standard errors. Tropical/subtropical, $\mathrm{n}=4$; Temperate, $\mathrm{n}=11$; Boreal, $\mathrm{n}=5$. Different letters above the bars indicate significant differences at the level of $p<0.05$ for GPP and RE, and $p<0.1$ for NEP respectively). GPP and RE consistently ranked in decreasing order as tropical/subtropical $>$ temperate $>$ boreal (Fig. 1b, c). NEP of afforestation was higher in tropical/subtropical and temperate zones than that in boreal zones (Fig. 1a).

\section{Carbon exchange variation by land use type prior to afforestation}

Previous land use type did not affect rates of carbon sequestration (Fig. 2). Afforestation of grassland yielded marginally higher NEP, GPP and RE than did farmland or pasture. But after eliminating the effects of climate, tree species, and age of afforestation, grassland, farmland and pasture were similar in terms of NEP, GPP, and RE (ANCOVA) (Fig. 2).

\section{Carbon exchange variation by afforestation tree species}

The species of tree used in afforestation did not affect carbon fluxes (Fig. 3). NEP declined from spruce stands $\left(341 \pm 120 \mathrm{~g} \mathrm{C} \mathrm{m}^{-2} \mathrm{a}^{-1}\right)$ to pine $\left(267 \pm 92 \mathrm{~g} \mathrm{C} \mathrm{m}^{-2}\right.$ $\left.\mathrm{a}^{-1}\right)$ to broadleaf trees $\left(219 \pm 111 \mathrm{~g} \mathrm{C} \mathrm{m}^{-2} \mathrm{a}^{-1}\right)$, but means were not statistically different (ANCOVA, $p>0.05$ ) (Fig. 3a). Similar GPP and RE were obtained between the different tree species (ANCOVA, $p>0.05$; Fig. 3b, c).

\section{Carbon exchange variation by age of afforestation}

Carbon fluxes varied by age of afforestation (ANCOVA, $p<0.05)$. NEP and GPP varied by age group and exhibited different dynamic patterns over time (Fig. 4). NEP was initially low at $<10$ years after afforestation, peaked at 10-20 years and then decreased with increasing age of afforestation (Fig. 4a). GPP tended to increase during the initial stage, peaked at 10-20 years, and then decreased at 20-40 years. There was a slight increase in GPP at $>40$ years after afforestation (Fig. 4b). The variation of RE with age of afforestation was not as significant as that of GPP, but RE followed a similar dynamic pattern. RE increased gradually at the early stage of $<20$ years and then decreased at 20-40 years. Also, there was a relative increase in RE at $>40$ years after afforestation (Fig. 4c).

\section{The effects of climate factors and age on carbon exchange of afforestation}

Mean annual temperature and precipitation influenced carbon flux after afforestation (Fig. 5). After detrending the effects of age of afforestation, NEP increased significantly with mean annual temperature $\left(R^{2}=0.27, p<0.001\right)$ and 


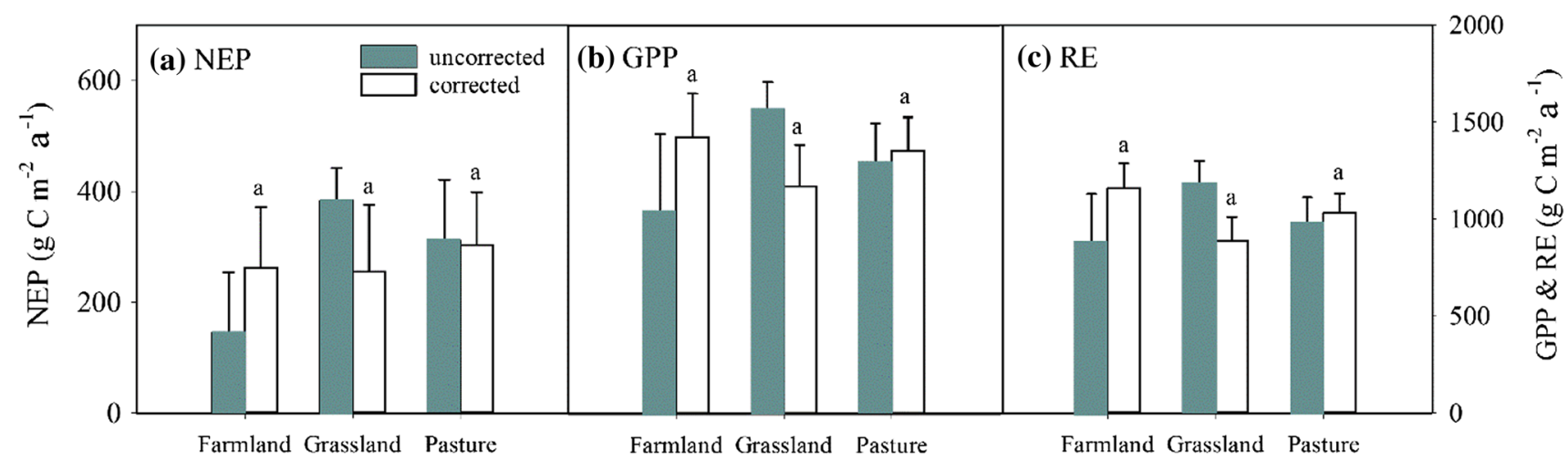

Fig. 2 Carbon exchange in different previous land use types of afforestation. a NEP, net ecosystem production; $\mathbf{b}$ GPP, gross primary production; c RE, ecosystem respiration. The error bars represent standard errors. Farmland, $\mathrm{n}=7$; Grassland, $\mathrm{n}=6$; Pasture, $\mathrm{n}=7$. Different letters above the bars indicate significant differences at the level of $p<0.05$

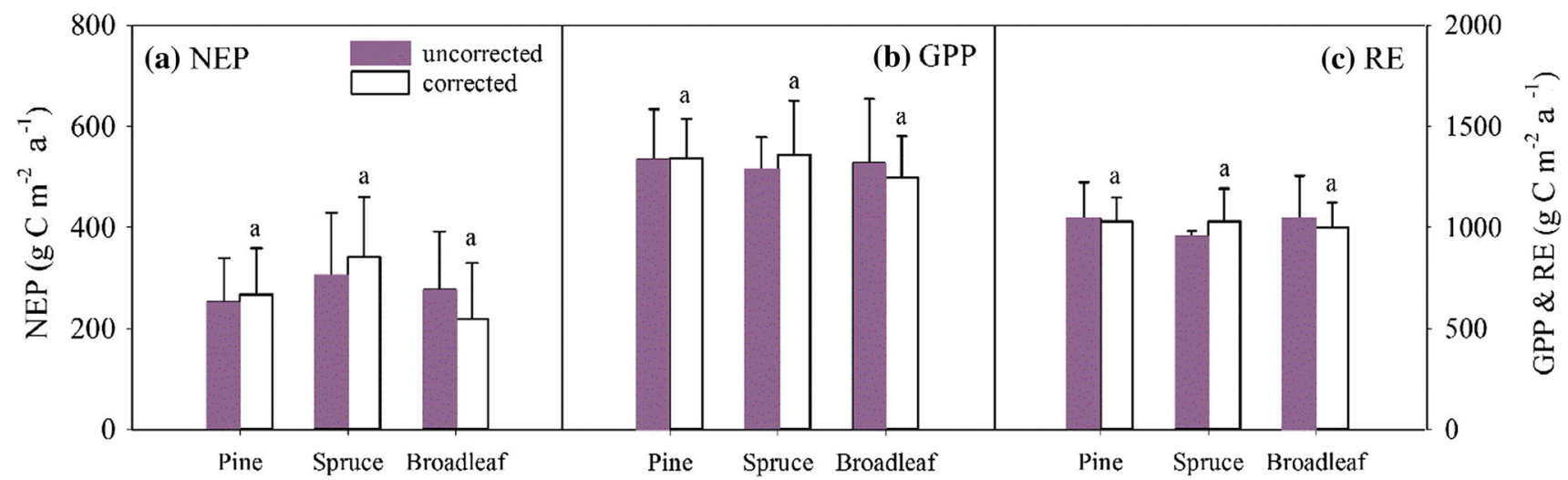

Fig. 3 Carbon sequestration with different afforested tree species. a NEP, net ecosystem production; b GPP, gross primary production; c RE, ecosystem respiration. The error bars represent standard errors.

mean annual precipitation $\left(R^{2}=0.31, p<0.001\right)$ (Fig. 5a, d). GPP and RE both showed linear increases with temperature (Fig. 5b, c) and precipitation (Fig. 5e, f).

Given the dominant influences of climate factors and age of afforestation, we used the developed general linear model to quantify individual and interactive effects of these factors. The results showed that climate factors, age of afforestation and their interactive effects jointly accounted for $51 \%, 61 \%$ and $63 \%$ of the post-afforestation variation in NEP, GPP and RE, respectively (Fig. 6). Variations of GPP and RE were primarily influenced by temperature, while NEP was more sensitive to the change of age of afforestation, which individually explained $20 \%$ of the variation in NEP (Fig. 6).
Pine, $\mathrm{n}=8$; Spruce, $\mathrm{n}=5$; Broadleaf, $\mathrm{n}=7$. Different letters above the bars indicate significant differences at the level of $p<0.05$

\section{Discussion}

\section{Climate}

Climate can affect carbon sequestration through processes associated with vegetation production and biological respiration. At the global scale, plant productivity and metabolic rates vary with climate (Beer et al. 2010; BondLamberty and Thomson 2010). Across climate zones from tropical, temperate to boreal, there is a gradually decreasing trend in ecosystem production, respiration and net carbon sequestration (Luyssaert et al. 2007; FernándezMartínez et al. 2014). Our results demonstrated that postafforestation carbon exchange followed the same pattern found in natural ecosystems. NEP, GPP and RE followed the consistent decreasing order of tropical/subtropical $>$ temperate $>$ boreal. This suggests that afforestation in subtropical and temperate zones have greater carbon sink capacities than do boreal zones.

Climate zones are characterized by a combination of mean annual temperature and precipitation, which are 


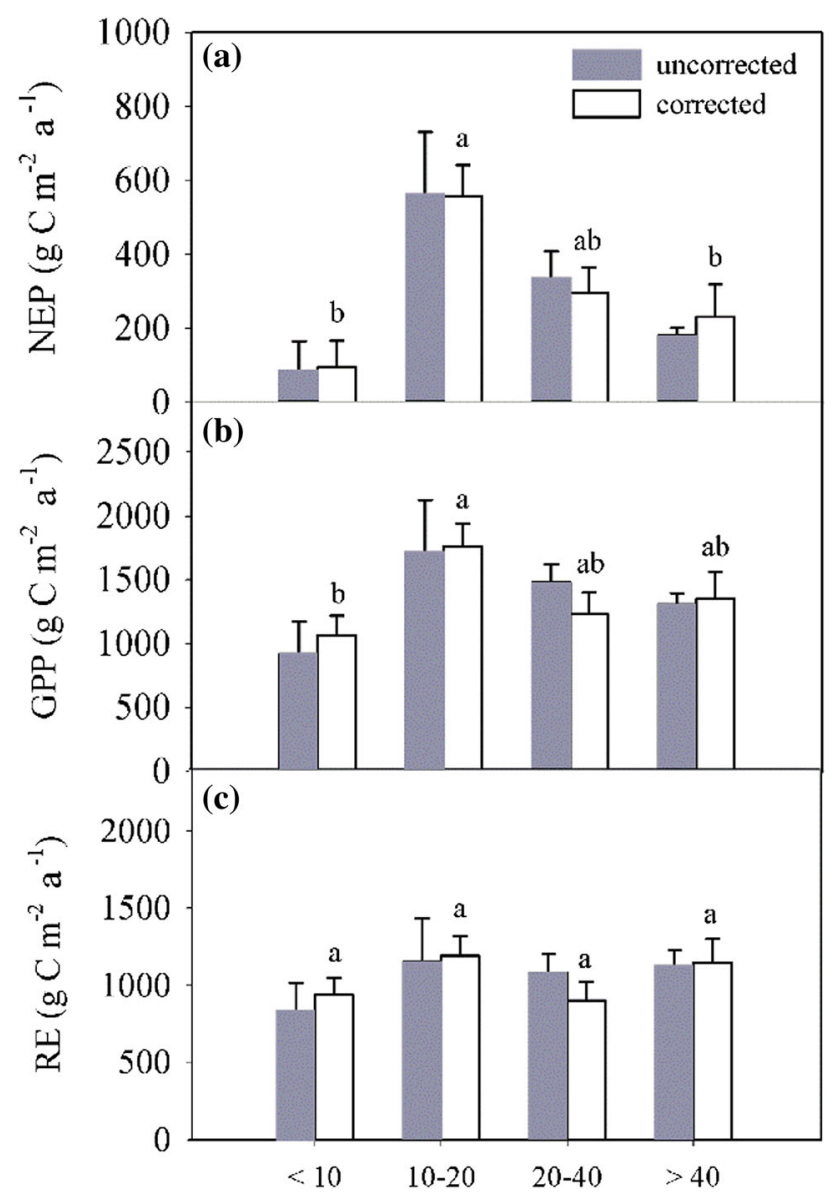

Fig. 4 Carbon exchange in different ages of afforestation. a NEP, net ecosystem production; b GPP, gross primary production; c RE, ecosystem respiration. The error bars represent standard errors. Age of afforestation $<10, \mathrm{n}=6 ; 10-20, \mathrm{n}=4 ; 20-40, \mathrm{n}=6 ;>40$, $\mathrm{n}=4$. Different letters above the bars indicate significant differences at the level of $p<0.05$

factors affecting carbon exchange processes. Our results showed that NEP, GPP and RE of afforested lands all significantly increased with increasing mean annual temperature and precipitation (Fig. 5). This result adequately explains the increasing trend of carbon fluxes from cold and arid to warm and humid climate zones. Warmer temperature and greater precipitation effectively prolong the growing season length, enhance the photosynthetic capacity and microbial activity, and thus promote plant growth and respiration (Kato and Tang 2008; Chen et al. 2013). Our results also indicated that the positive climate effects were more predominant on GPP and RE than on NEP. This result confirms reports on natural ecosystems (Law et al. 2002; Chen et al. 2013). Owing to the net balance between GPP and RE, the direct regulation of climate on NEP is likely weakened by the parallel responses of production and respiration. In contrast, NEP is more sensitive to biotic factors, such as the age of afforestation, as reported by others (Law et al. 2002; Thornton et al. 2002) and documented here.

\section{Previous land use type}

Previous types of land use might affect the rate of plant and soil carbon sequestration due to the altered vegetation and soil conditions. For example, grasslands tend to accumulate soil $\mathrm{C}$ at faster rates than agricultural sites (Silver et al. 2000; Kukal and Bawa 2014; Liu et al. 2018). Generally, cultivated or pasture lands are characterized by low soil nutrient levels because of a depletion of organic matter inputs by human activities (Kukal and Bawa 2014; Liu et al. 2018). In contrast, natural grasslands continuously maintain vegetation cover on the soil, and can have high rates of accumulation and turnover that add organic matter from below ground to the soil ( $\mathrm{Li}$ et al. 2012). Our results indicated that afforestation of grassland yielded higher plant production and ecosystem respiration than did afforestation of farmland or pasture. However, after factoring out the effects of climate, age and tree species, there was no significant difference in either production or respiration among grassland, farmland and pasture. This to some extent demonstrates the dominant influences of climate and age on the variation in post-afforestation carbon exchange.

\section{Tree species planted}

The planted tree species probably influence the rate of carbon exchange by their different leaf traits, photosynthetic capacities, and litterfall qualities. Many studies have documented that $\mathrm{C}$ sequestration in soil is strongly influenced by the species of trees planted on afforestation sites (Paul et al. 2002; Berthrong et al. 2009; Laganière et al. 2010; Li et al. 2012). Broadleaf trees tend to increase soil C sequestration while coniferous trees either have no effect or reduce soil C sequestration (Paul et al. 2002; Laganière et al. 2010). Our results showed that ecosystem carbon sequestration did not vary by tree species. This result was supported by a meta-analysis that revealed no significant differences in carbon fluxes between coniferous and broadleaf forests (Fernández-Martínez et al. 2014). Although needle-leaves generally have lower photosynthetic efficiencies and decomposition rates than broadleaves (Lusk et al. 2003), needleleaved forests have approximately 2.8 times more foliar biomass than broadleaved forests (Fernández-Martínez et al. 2014). The offsets between metabolic rate and leaf quantity probably contribute to the comparability of ecosystem carbon sequestration between coniferous and broadleaf forests. 
Fig. 5 Relationships between carbon fluxes (NEP, GPP, RE) and mean annual temperature $(\mathbf{a}-\mathbf{c})$ and mean annual precipitation $(\mathbf{d}-\mathbf{f})$. The red dashed lines indicate the $95 \%$ confidence intervals of the regressions
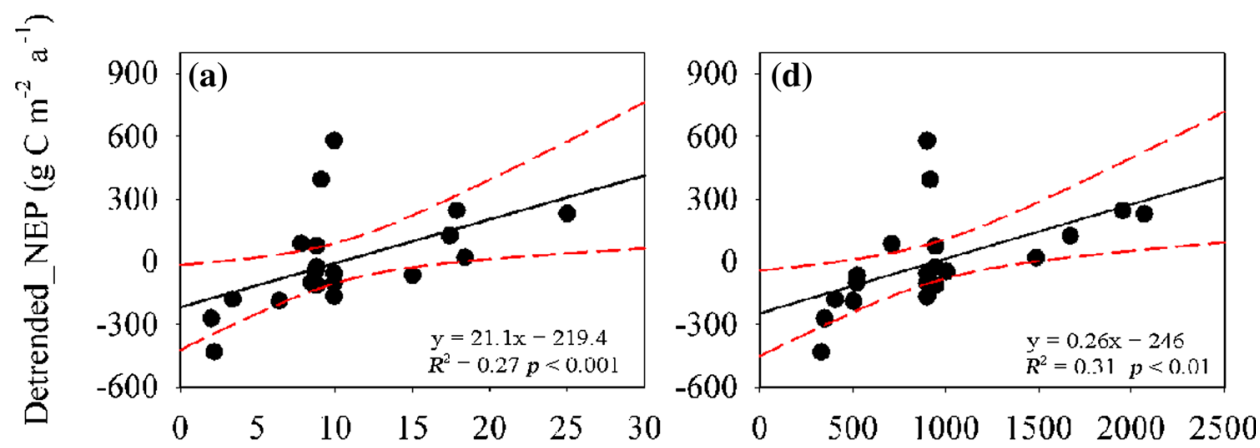

T 2000

i.

U

un

1500

(b)

1000

京
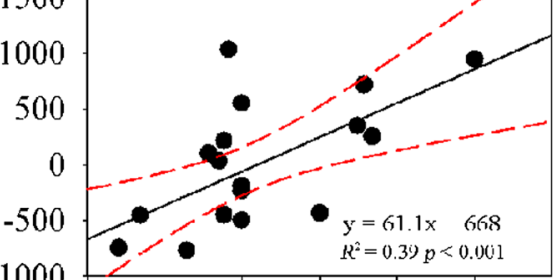

$-1000+20-1000$

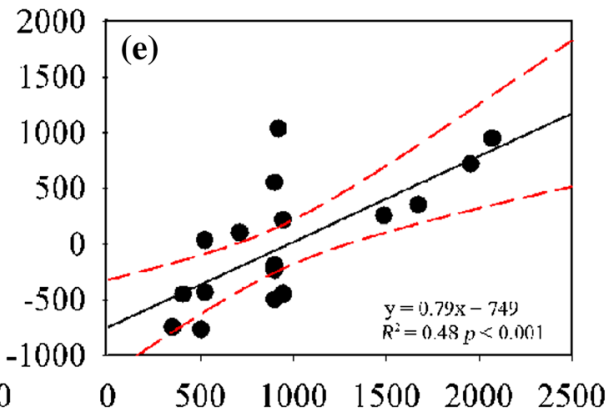

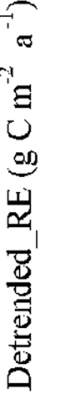
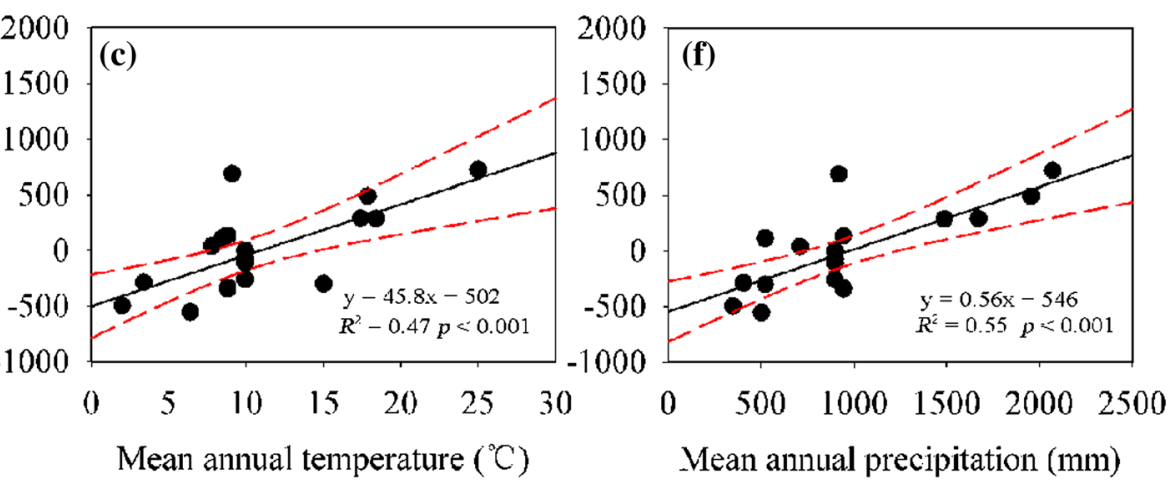

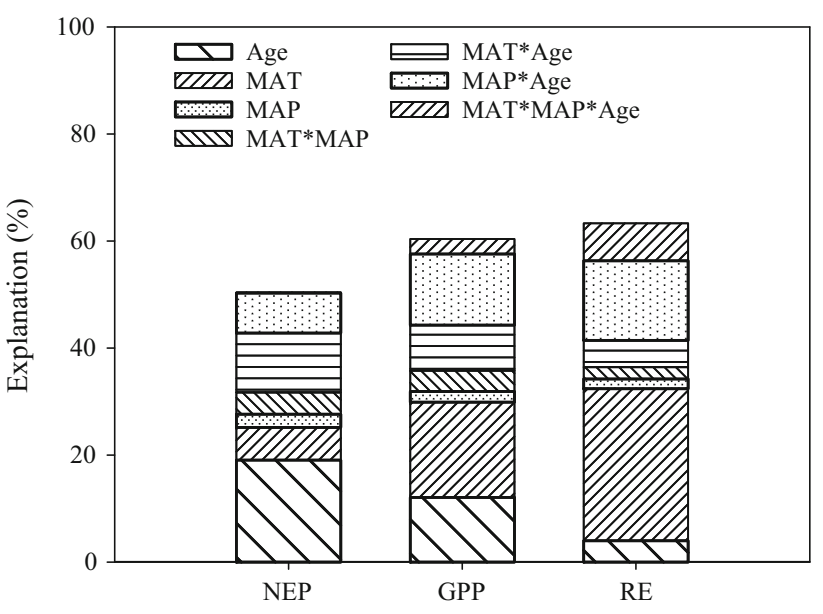

Fig. 6 Interactive effects of climate factors and age on carbon fluxes of afforestation. MAT mean annual temperature, $M A P$ mean annual precipitation, $N E P$ net ecosystem production, GPP gross primary production, $R E$ ecosystem respiration

\section{Age of afforestation}

Age of afforestation has a significant influence on carbon exchange in afforested land. Our results showed that age of afforestation together with climate zone jointly accounted for $51 \%$ of the variation in NEP, of which $20 \%$ was attributable to age of afforestation alone (Fig. 6). NEP varied by age group (Fig. 4). At the initial stage of afforestation $(<10$ years), NEP approached zero, indicating that ecosystems are generally weak carbon sources or are carbon neutral during the early stages of afforestation. NEP gradually increased and peaked during 10-20 years after afforestation, and subsequently declined. This temporal pattern of post-afforestation NEP was consistent with patterns documented for natural and secondary succession (Pregitzer and Euskirchen 2004; Goulden et al. 2011). Chronological studies indicate that forest NEP is initially negative after a disturbance; the ecosystem transitions from a carbon source to a sink at 10-20 years, peaks during the 
middle stage of 20-50 years, and then declines at older stages (Pregitzer and Euskirchen 2004; Amiro et al. 2006; Goulden et al. 2011). Our results indicated that relative to natural and secondary succession, afforestation showed a quicker transition from a carbon source to a sink and exhibited an earlier peak. This quick recovery reflects the rapid growth of planted trees and acceleration of growth by human management of afforested lands (Berthrong et al. 2009).

How NEP varies with age of afforestation directly depends on the dynamic patterns of GPP and RE. Our results showed that after afforestation, GPP tended to gradually increase to its highest value at 10-20 years and then decreased. Variation in RE paralleled that of GPP. At the early stage of afforestation, ecosystems acted as weak carbon sources because GPP was constrained by the low foliar biomass, while large residuals in the ground and soil decompose rapidly under the influence of land preparation. With the rapid expansion of leaves, GPP rapidly increases and reaches its peak at the medium stage of 10-20 years. After the canopy is fully closed, GPP gradually declines with stand age (Peichl et al. 2010; Coursolle et al. 2012). Our results also demonstrated that there were slight increases in GPP and RE at the late stage of $>40$ years after afforestation. These increases were attributed in part to the expanded community of understory shrubs and herbs and increased fine root turnover and root metabolism at the late stage as reported by Goulden et al. (2011). We found that afforested stands showed their most rapid carbon sequestration at 10-20 years, which suggests that management practices such as timber harvest should be carried out after 20-30 years to obtain the greatest carbon sequestration benefits.

\section{Uncertainties}

As is common in literature reviews, uncertainties might have been introduced to results due to differing observation approaches, data analysis methods, and other factors. To reduce the errors caused by varied approaches, we only assessed carbon exchange as reported based on the eddy covariance technique. Based on eddy measurement, the carbon sequestration of afforestation was estimated to be $468 \pm 130,314 \pm 78$, and $34 \pm 119 \mathrm{~g} \mathrm{C} \mathrm{m}^{-2} \mathrm{a}^{1}$ in trop$\mathrm{ical} /$ subtropical, temperate and boreal zones respectively. This result is consistent with the reports of carbon budget inventories which documented average rates of uptake for afforestation in tropical, temperate and boreal zones as 400-800, 150-450, and 40-120 $\mathrm{g} \mathrm{C} \mathrm{m}^{-2} \mathrm{a}^{-1}$, respectively (IPCC 2000; Liu et al. 2016). However, we note that there are large variations in estimates associated with both methods, especially in tropical and boreal zones. Carbon sequestration showed high sensitivity to land use in tropical and boreal zones where there were few reported measurements (Wolf et al. 2011). In future studies, more comparative measurements in tropical and boreal areas are needed for a greater understanding of carbon balance after afforestation.

\section{Conclusions}

Ecosystem carbon sequestration after afforestation greatly varied among different climate zones, while it was weakly influenced by previous land use and tree species. Climate zone and age of afforestation were the dominant factors influencing carbon sequestration, and jointly accounted for $51-63 \%$ of the variation in NEP, GPP and RE. Compared to the dominant effect of climate on GPP and RE, NEP was more sensitive to age of afforestation. These results add to our knowledge of the variation in ecosystem carbon exchange after afforestation. To more accurately assess the carbon balance it will be necessary to conduct more studies, especially in climate-sensitive and labile areas such as tropical and boreal zones.

Open Access This article is distributed under the terms of the Creative Commons Attribution 4.0 International License (http://crea tivecommons.org/licenses/by/4.0/), which permits unrestricted use, distribution, and reproduction in any medium, provided you give appropriate credit to the original author(s) and the source, provide a link to the Creative Commons license, and indicate if changes were made.

\section{References}

Amiro BD, Barr AG, Black TA, Iwashita H, Kljun N, McCaughey JH, Morgenstern K, Murayama S, Nesic Z, Orchansky AL, Saigusa $\mathrm{N}$ (2006) Carbon, energy and water fluxes at mature and disturbed forest sites, Saskatchewan, Canada. Agric For Meteorol 136:237-251

Arain MA, Coupe NR (2005) Net ecosystem production in a temperate pine plantation in southeastern Canada. Agric For Meteorol 128:223-241

Beer C, Reichstein M, Tomelleri E, Ciais P, Jung M, Carvalhais N, Rdenbeck C, Arain MA, Dennis Baldocchi, Bonan GB, Bondeau A, Cescatti A, Lasslop G, Lindroth A, Lomas M, Luyssaert S, Margolis H, Oleson KW, Roupsard O, Veenendaal E, Viovy N, Williams C, Woodward FI, Papale D (2010) Terrestrial gross carbon dioxide uptake: global distribution and covariation with climate. Science 329:834-838

Berthrong ST, Jobbágy EG, Jackson RB (2009) A global metaanalysis of soil exchangeable cations, $\mathrm{pH}$, carbon, and nitrogen with afforestation. Ecol Appl 19:2228-2241

Bjarnadottir B, Sigurdsson BD, Lindroth A (2009) Seasonal and annual variation of carbon fluxes in a young Siberian larch (Larix sibirica) plantation in Iceland. Biogeosciences 6:6601-6634

Black K, Byrne KA, Mencuccini M, Tobin B, Nieuwenhuis M, Reidy B, Bolger T, Saiz G, Green C, Farrell ET, Osborne B (2009) 
Carbon stock and stock changes across a Sitka spruce chronosequence on surface-water gley soils. Forestry 82:255-272

Bond-Lamberty B, Thomson A (2010) A global database of soil respiration data. Biogeosciences 7:1915-1926

Cai TB, Price D, Orchansky A, Thomas B (2011) Carbon, water, and energy exchanges of a hybrid poplar plantation during the first five years following planting. Ecosystems 14:658-671

Chen Z, Yu GR, Ge JP, Sun XM, Hirano T, Saigusa N, Wang QF, Zhu XJ, Zhang YP, Zhang JH (2013) Temperature and precipitation control of the spatial variation of terrestrial ecosystem carbon exchange in the Asian region. Agric For Meteorol 182-183:266-276

Coursolle C, Margolis HA, Giasson MA, Bernier PY, Amiro BD, Arain MA, Barr AG, Black TA, Goulden ML, McCaughey JH, Chen JM, Dunn AL, Grant RF, Lafleur PM (2012) Influence of stand age on the magnitude and seasonality of carbon fluxes in Canadian forests. Agric For Meteorol 165:136-148

Don A, Rebmann C, Kolle O, Scherer-Lorenzen M, Schulze E-D (2009) Impact of afforestation-associated management changes on the carbon balance of grassland. Glob Change Biol 15:1990-2002

FAO (2017) FAOSTAT. http://www.fao.org/faostat/en/\#data/RL

Fernández-Martínez M, Vicca S, Janssens IA, Luyssaert S, Campioli M, Sardans J, Estiarte M, Peñuelas J (2014) Spatial variability and controls over biomass stocks, carbon fluxes, and resourceuse efficiencies across forest ecosystems. Trees 28:597-611

Goulden ML, McMillan AMS, Winston GC, Rocha AV, Manies KL, Harden JW, Bond-Lamberty BP (2011) Patterns of NPP, GPP, respiration, and NEP during boreal forest succession. Glob Change Biol 17:855-871

Guo L, Gifford R (2002) Soil carbon stocks and land use change: a meta analysis. Glob Change Biol 8:345-360

Han S (2008) Productivity estimation of the poplar plantations on the beaches in middle and low reaches of Yangtze river using eddy covariance measurement. Doctoral Dissertation, Chinese Academy of Forestry

Huang M, Ji JJ, Li KR, Liu YF, Yang FT (2007) The ecosystem carbon accumulation after conversion of grasslands to pine plantations in subtropical red soil of south China. Tellus Ser B Chem Phys Meteorol 59:439-448

IPCC (Intergovernmental Panel on Climate Change) (2000) IPCC special report: land use, land-use change, and forestry. Cambridge University Press, Cambridge

Jandl R, Lindner M, Vesterdal L, Bauwens B, Baritz R, Hagedorn F, Johnson DW, Minkkinen K, Byrne KA (2007) How strongly can forest management influence soil carbon sequestration? Geoderma 137:253-268

Jassal RS, Black TA, Arevalo C, Jones H, Bhatti JS, Sidders D (2013) Carbon sequestration and water use of a young hybrid poplar plantation in north-central Alberta. Biomass Bioenergy 56:323-333

Kato T, Tang Y (2008) Spatial variability and major controlling factors of $\mathrm{CO}_{2}$ sink strength in Asian terrestrial ecosystems: evidence from eddy covariance data. Glob Change Biol 14:2333-2348

Kukal SS, Bawa SS (2014) Soil organic carbon stock and fractions in relation to land use and soil depth in the degraded Shiwaliks hills of lower Himalayas. Land Degrad Dev 25:407-416

Laganière J, Angers DA, Paré D (2010) Carbon accumulation in agricultural soils after afforestation: a meta-analysis. Glob Change Biol 16:439-453

Lal R (2008) Carbon sequestration. Philos Trans R Soc 363:815-830

Law BE, Falge E, Gu L, Baldocchi DD, Bakwin P (2002) Environmental controls over carbon dioxide and water vapour exchange of terrestrial vegetation. Agric For Meteorol 113:97-120
Li DJ, Niu SL, Luo YQ (2012) Global patterns of the dynamics of soil carbon and nitrogen stocks following afforestation: a metaanalysis. New Phytol 195:172-181

Liu WW, Wang XK, Lu F, Ouyang ZY (2016) Influence of afforestation, reforestation, forest logging, climate change, $\mathrm{CO}_{2}$ concentration rise, fire, and insects on the carbon sequestration capacity of the forest ecosystem. Acta Ecol Sin 36(8):2113-2122

Liu X, Yang T, Wang Q, Huang FR, Li LH (2018) Dynamics of soil carbon and nitrogen stocks after afforestation in arid and semiarid regions: a meta-analysis. Sci Total Environ 618:1658-1664

Lohila A, Laurila T, Aro L, Aurela M, Tuovinen JP, Laine J, Kolari P, Minkkinen K (2007) Carbon dioxide exchange above a 30-yearold Scots pine plantation established on organic-soil cropland. Boreal Environ Res 12:141-157

Lusk CH, Wright I, Reich PB (2003) Photosynthetic differences contribute to competitive advantage of evergreen angiosperm trees over evergreen conifers in productive habitats. New Phytol 160:329-336

Luyssaert S, Inglima I, Jung M, Richardson AD, Reichsteins M, Papale D, Piao SL, Schulzes ED, Wingate L, Matteucci G (2007) $\mathrm{CO}_{2}$ balance of boreal, temperate, and tropical forests derived from a global database. Glob Change Biol 13:2509-2537

Metz B, Davidson OR, Bosch PR, Dave R, Meyer LA (2007) Contribution of working group III to the fourth assessment report of the intergovernmental panel on climate change. Cambridge University Press, Cambridge

Meyer A, Tarvainen L, Nousratpour A, Björk RG, Ernfors M, Grelle A, Klemedtsson ÅK, Lindroth A, Räntfors M, Rütting T, Wallin G, Weslien P, Klemedtsson L (2013) A fertile peatland forest does not constitute a major greenhouse gas Sink. Biogeosciences 10:7739-7758

Paul KI, Polglase PJ, Nyakuengama JG, Khanna PK (2002) Change in soil carbon following afforestation. For Ecol Manag 168:241-257

Peichl M, Brodeur JJ, Khomik M, Arain MA (2010) Biometric and eddy-covariance based estimates of carbon fluxes in an agesequence of temperate pine forests. Agric For Meteorol 150:952-965

Peichl M, Arain AM, Moore TR, Brodeur JJ, Khomik M, Ullah S, Restrepo-Coupé N, McLaren J, Pejam MR (2014) Carbon and greenhouse gas balances in an age sequence of temperate pine plantations. Biogeosciences 11:5399-5410

Pregitzer KS, Euskirchen ES (2004) Carbon cycling and storage in world forests: biome patterns and related to forest age. Glob Change Biol 10:2052-2077

Silver W, Ostertag R, Lugo A (2000) The potential for carbon sequestration through reforestation of abandoned tropical agricultural and pasture lands. Restor Ecol 8:394-407

Six J, Elliott ET, Paustian K (2000) Soil macroaggregate turnover and microaggregate formation: a mechanism for $\mathrm{C}$ sequestration under no-tillage agriculture. Soil Biol Biochem 32:2099-2103

Tang YK, Chen YM, Wen XF, Sun XM, Wu X, Wang HM (2016) Variation of carbon use efficiency over ten years in a subtropical coniferous plantation in southeast China. Ecol Eng 97:196-206

Thornton PE, Law BE, Gholz HL, Clark KL, Falge E, Ellsworth DS, Goldstein AH, Monson RK, Hollinger D, Falk M, Chen J, Sparks JP (2002) Modeling and measuring the effects of disturbance history and climate on carbon and water budgets in evergreen needleleaf forests. Agric For Meteorol 113:185-222

Tong XJ, Meng P, Zhang JS, Li J, Zheng N, Huang H (2012) Ecosystem carbon exchange over a warm-temperate mixed plantation in the lithoid hilly area of the North China. Atmos Environ 49:257-267

Wolf S, Eugster W, Potvin C, Turner BL, Buchmann N (2011) Carbon sequestration potential of tropical pasture compared with afforestation in Panama. Glob Change Biol 17:2763-2780 
Wright JA, DiNicola A, Gaitan E (2000) Latin American forest plantations-opportunities for carbon sequestration, economic development, and financial returns. J For 98:20-23
Publisher's Note Springer Nature remains neutral with regard to jurisdictional claims in published maps and institutional affiliations. 